\title{
Lagging laws
}

\author{
The validity of a 1999 German patent on the derivation of neural precursors from human embryonic stem cells \\ remains undecided, highlighting the inadequacy of European law for dealing with stem cell technology.
}

L ast November, the German Federal High Court of Justice (Bundesgerichtshof, BGH) declared itself unable to render a final decision in a long-running patent dispute between neuroregeneration researcher Oliver Brüstle and the activist group Greenpeace. It will instead submit the case to the European High Court of Justice. The European court's decision is expected to take another 1-2 years. In the meantime, the furious progress of stem cell science has rendered almost moot the bioethical concerns underlying the dispute. The case starkly illuminates the inadequacy of current German and European Union (EU) laws for trying to regulate a fast-moving area of science.

Brüstle originally submitted his patent application on a method to generate neuronal and glial precursor cells from embryonic stem (ES) cell lines for transplantation therapy to the German Patent Office in 1997. The patent was written to broadly cover mammalian species including humans, all of the then-known sources of ES cells and possible therapeutic application to many diseases. It was granted by the German patent office in 1999.

At the time, German patent law did not include any special regulations regarding human ES cells (hESCs). Brüstle's work kicked off passionate public discussion about its ethical implications. In 1998, the European Parliament had issued a 'Directive on Biotechnological Inventions', which, in Article 6, forbids the granting of patents if "their commercial exploitation would be contrary to ordre public or morality," which includes "uses of human embryos for industrial or commercial purposes." In 2004, Greenpeace sued for revocation of Brüstle's patent, primarily on the basis of the EU Directive. In 2005 ( 5 years after the deadline set by the EU), German patent law was amended to include the EU Directive. In 2006, the German Federal Patent Court revoked Brüstle's patent insofar as it referred to embryoderived human ES cells and cell lines.

Brüstle appealed to the $\mathrm{BGH}$, arguing that the patented methodology, based on already available ES cell lines, does not destroy any embryos. Furthermore, as his research on human embryo-derived ES cell lines was legal, it appeared to be inconsistent to then forbid the patenting of the research results. Instead of issuing a judgment, however, the BGH decided to ask the European high court for a decisive interpretation of Article 6 of the Directive, which would then be binding for the German courts as well. Brüstle expects his case to be resolved in 2010 or 2011.

In the interim, the stem cell field has made enormous progress. Induced pluripotent stem (iPS) cells, unknown at the time of Brüstle's patent application, are now considered to be the most promising source of human pluripotent cells, with applications for disease modeling, drug development and, in the future, transplantation therapy. iPS cells can be derived from adult somatic cells, minimizing the ethical concerns that have led to the poorly defined "ordre public and morality" phrases in the law. Current iPS cell-derived grafts are prone to cancerous growth in animal models because of the viral overexpression of pluripotencyinducing transcription factors that can be oncogenic. This problem may be overcome by very recent protocols that induce pluripotency in human skin cells while avoiding viral vectors.

Given the promise and ethical inoffensiveness of the iPS cell methodology, the whole basis of Greenpeace's challenge to Brüstle's patent appears almost obsolete. The patent itself, however, may well remain relevant in the near future, as the methods developed to derive neural precursors from ES cells are directly applicable to other pluripotent cells, including iPS cells. Thus, Brüstle emphasizes the importance of achieving a resolution to his case. Having been referred to the European high court, he hopes that it will serve as a precedent relevant to the entire EU, clarifying the definitions of both public order and morality and indeed the human embryo.

Obviously, a law based on public order and morality will lead to contradictory outcomes, as the understanding of morality in modern societies can vary from courtroom to courtroom. In the US, federal funding for stem cell research was, until recently, based on morality as defined by the Bush administration, whereas state and private funders were allowed to act on their own, entirely different moral standards. Similarly, European legislation and regulations of human embryo and stem cell research vary substantially from country to country. Germany is one of the strictest, with derivation of hESCs from embryos being entirely forbidden. hESC lines may be imported, but any research involving them requires a special exemption granted by a central bioethics committee. In the UK, in contrast, human zygotes and blastulas are not granted the same legal status as embryos 14 days old or older; therefore, the derivation of hESCs from blastulas, as well as any research and development involving hESCs, including its patent protection, is not subject to substantial restrictions. The European situation is further complicated by the existence of both national and European patent offices and courts. With a nebulous law and a dual-track system, it is no wonder that it is taking 7 years to sort out Greenpeace vs. Brüstle.

Everyone, scientists and taxpayers, fervently hopes that stem cell research will eventually translate into treatments for the neurodegenerative diseases that become ever more common as populations age. Development of new therapies is always very costly and no one will undertake it if they cannot secure their investments with patent protection. Greenpeace vs. Brüstle clearly demonstrates the inadequacy of German and European biotechnology patent legislation in dealing with the rapidly advancing stem cell field. As the case slowly wends its way through the halls of justice, European lawmakers should make the drafting of more practical, applicable and science-friendly laws a priority. 